\title{
Psychological Effects of Attachment on the User Application SPSS with Technology Acceptance Model
}

\author{
Dyah Pratiwi \\ Faculty of Computer Science, Gunadarma University \\ Jl. Margonda Raya No. 100, Depok 16424, West Java, Indonesia
}

\begin{abstract}
This study aims to analyze the influence of psychological attachment (Internalization, identification, and compliance) to the use of SPSS with the Technology Acceptance Model approach. The survey has been conducted on final candidates for bachelor's degree students at a college psychologi $X$ in Jakarta. The results of this study indicate that the identification is the most dominant factor explaining Psychological Attachment. Identification significant effect on user attitudes SPSS. This study also proves that the Psychological Attachment significant effect on behavior intention either directly or indirectly via attitudes towards the use of SPSS application. In addition, this study also proves that the psychological attachment directly significant effect on the use of SPSS.
\end{abstract}

\section{General Terms}

Application Information System

\section{Keywords}

Keywords: SPSS application, and TAM psychological attachment.

\section{INTRODUCTION}

Phase application of technology that matters to the user is the technology adoption process and the transfer of technology to improve the competence of the user. The most dominant factor here is the availability of human resources capable of adoption, both as a carrier and switching technology knowledge and skills as well as the recipient of such technology.

The focus of this study is whether students of psychology S1responsive to information technology, especially the use of SPSS. To find out how to use SPSS Student $t$ can be measured by the adoption of information technology known as the analysis of the Technology Acceptance Model (TAM), which includes Perceived Usefulness (PU), Perceived Ease of Use (PEOU), Attitude Toward Using (ATU), Behavioral intention (BI) and Actual Use (AU) as measured by perceptions of final year students and prospective graduate diploma psychology courses who will enter the workforce.

TAM includes an important theoretical contribution to the understanding of the use of the IS (Information System) and how IS acceptance [1]. However, as noted by several researchers IS [2], [1], Melone 1990 in [3], TAM incomplete in one important respect, namely TAM does not explain the psychological effect of the adoption and utilization Attachment The new IS. [1], [2] explains that it is important to explain the concept of subjective norms and understanding the concept of psychological influences including Attachment (Psychological Attachment). According to [4] Attachment Processes psychological influence or commonly called
Psychological Approach (Psychological Attachment) is divided into three parts, namely Internalization (INT), identification (IDN) and compliance (COMP).

Based on the description above, the formulation of the problem of this research is how the influence of psychological attachment that is Internalization, identification and compliance in the use of SPSS with the approach of the Technology Acceptance Model (TAM).

The limitation of this study is only a problem in the use of SPSS by a graduate student degree candidate S1-psychology courses at a university $\mathrm{X}$ in Jakarta when viewed from the influence of psychological attachment.

This study aims to give a general overview of the psychological effect of Attachment (Internalization, identification, and compliance) on the use of SPSS applications of psychology with TAM approach, while being specific objectives of this research are as follows:

1. To analyze the effect of PU, PEOU, PA to ATU partial and simultaneous.

2. To analyze the effect of PU, PEOU, PA, ATU against partial and simultaneous BI.

3. To analyze the effect of PU, PEOU, PA, ATU, BI against partial and simultaneous AU.

\section{LITERATURE REVIEW}

Several models have been built to analyze and understand the factors that influence the acceptance of the use of computer technology, such as that recorded in the literature and references to research in the field of information technology is like the Theory of Reasoned Action (TRA), Theory of SPSSnned Application Behavior (TPB), and Technology Acceptance Model (TAM) (Mhd. Jantan.et.al, 2001). TAM model developed by [2] is one of the most widely used models in IT research (see Igbaria.et.al, 1997; Adam.et.al, 1992; Mhd. Jantan.et.al. 2001; Chin and Todd, 1995), because this model is more simple, and easy to implement (Igbaria, 1995) in [5].

TAM model is actually adopted from the Theory of Reasoned Action models (TRA), the theory of reasoned action developed by Fishbein and Ajzen (1975) in [5]. TRA is a model widely used research drawn from psychology-related psychological attachment to things that affect conscious behavior that has the intent (Ajzen and Fishbein, 1977; Fishbein and Ajzen, 1975 in [3]. Based on TRA achievement is influenced by the specific behavior that is determined by the behavioral intention to use the system (Behaviral Intention) and $\mathrm{BI}$ is also determined by the user attitude towards the use of the system (Attitude Toward Using) and subjective norm (Subjective Norm) associated with the behavior in question [3]. 
TAM uses TRA as a theoretical basis for specifying the causal relationship between the two concepts: (1) the Perceived Usefulness (PU) and Perceived Ease of Use (PEOU), and (2)
User's Attitude (ATU) and Behavior Intention (BI) and Actual Computer Usage Behavior (AU) [3].

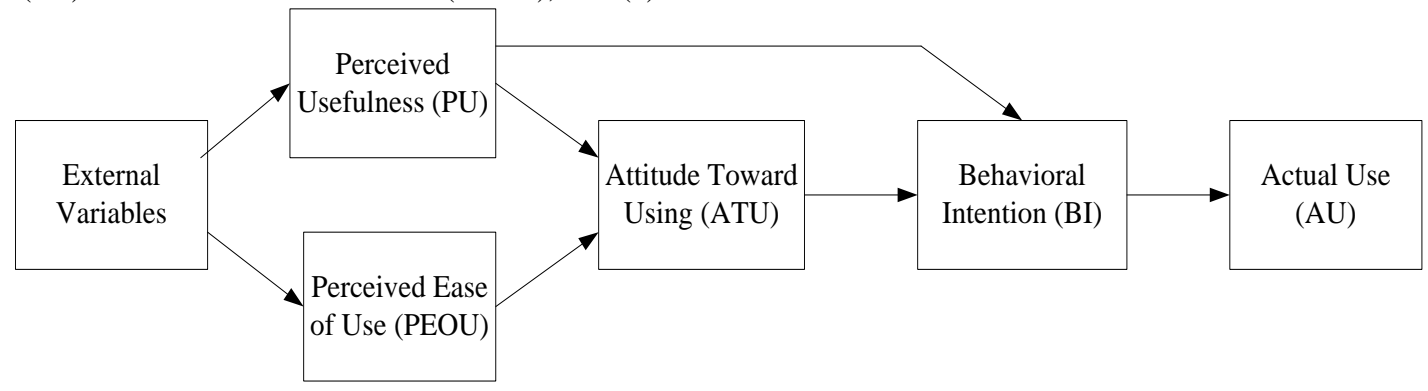

(Source : Davis et al. (1989) and Malhotra dan Galletta, (1999).

Figure 1. Technology Acceptance Model (TAM)

TAM includes an important theoretical contribution to the understanding of the use of the IS (Information System) and how IS acceptance [1]. However, as noted by several researchers IS [2], [1], Melone 1990 in [3], TAM incomplete in one important respect, namely TAM does not explain the psychological effect of the adoption and utilization Attachment The new IS. [2] and [1] explains that it is important to explain the concept of subjective norms and understanding the concept of psychological influence Attachment.

This study is based on TAM concept developed by [2] as shown in figure 1 , where the level of user acceptance of information technology is determined by the user's perception of the usefulness of the application of SPSS (perceived usefulness), user perception of ease of use application SPSS (perceived ease of use), the attitude of users towards the use of SPSS (attitude toward using), intention behavior in the use of SPSS (behavioral intention), and the use of SPSS (actual use) plus the extension taken from the theory of the influence of psychological attachment initiated by [4] or the so-called Psychological attachment, which contains the influence of psychological attachment to the intention of behavior (behavioral intention) and attitudes toward the use of technology (attitude toward Using). [4] distinguishes three processes influences that affect individual psychological attachment that internalization (Internalization), identification (identification) and compliance (Compliance).

Attachment psychological influence on research [4] is motivated by an interest in understanding the changes in the attitudes of each individual carried by an external input. $\mathrm{He}$ stated that the change in attitude and actions generated by the influence of psychological attachment that appears in the "levels" are different. According to the nature or degree of change that is associated with differences in the process of admission to the influence of individual or adjustment.

Psychological Attachment is the degree of commitment of the users of the application of information technology towards the use of the system by the effect of psychological influences on behavior Attachment [3]. Based on Kelman's framework, [1] have noted that the effects of psychological attachment can affect behavior intention (BI) indirectly through attitudes toward the use of technology (ATU), in connection with the internalization and identification, or affect BI directly through adherence (compliance). For more details, our model can be seen in Figure 2.

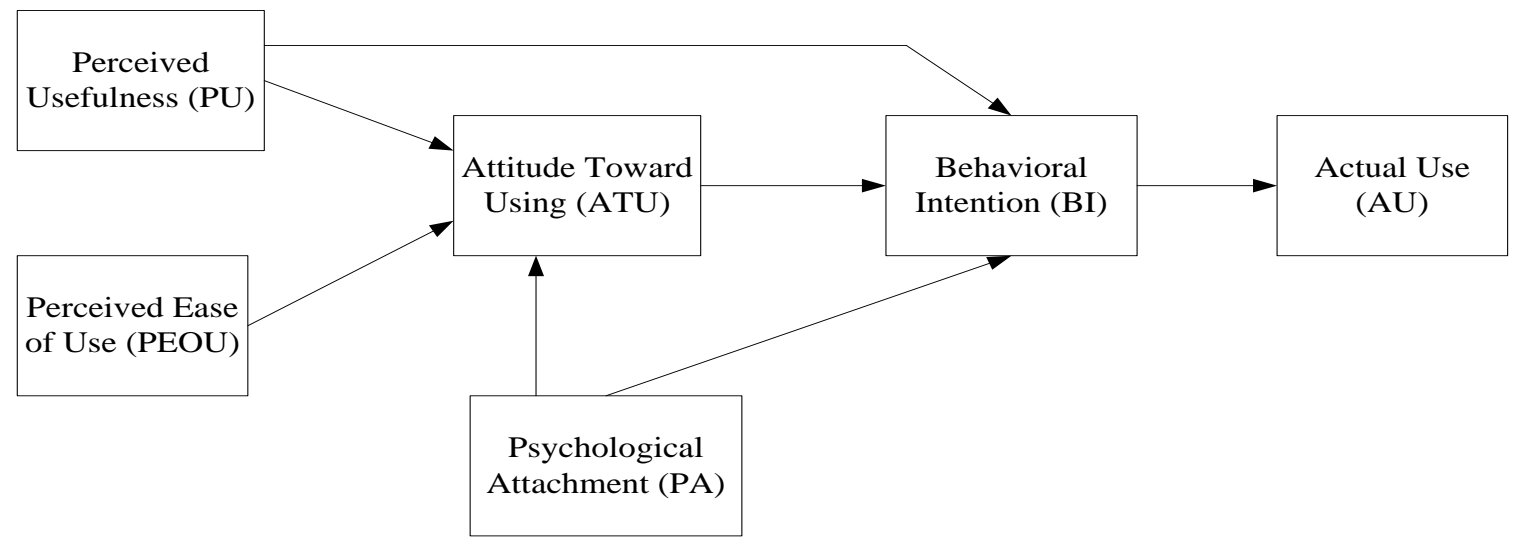

(Source : Malhotra and Galletta, 1999)

Figure 2. TAM in this research

TAM constructs used in this study are:

1. Perceived Usefulness (PU)

[6], quoted from [2]; [7] defined benefit (usefulness) as the degree to which a person believes that using a particular system would be able to improve the performance of the person. 
Based on the above definition can be interpreted that the benefits of the use of the computer is able to improve its performance and job performance.

2. Perceived Ease of Use (PEOU) According to [6], quoted from [2] defines ease of use (ease of use) as the degree to which a person believes that computers can be easily understood. According to Goodwin (1987); Silver (1988); Adam et.al (1992) in [5], intensity of use and the interaction between the user (users) with the system can also show that the system is better known, easier to operate and easier to use by users. Based on the definition above it can be concluded that the ease of use will reduce the effort, both in time and effort in studying computer person.

3. Attitude Toward Using (ATU)

In the research world, there are many definitions of attitude (attitude). [2] defines attitude toward the system used in the TAM as an assessment of the degree of impact experienced by a person when using a particular system in its work. Meanwhile, according to Fishbein and Ajzen (1975) in [3] defined attitude as a positive or negative feelings about targeting individual behavior.

4. Behavioral Intention (BI)

According to Fishbein and Ajzen (1975) in [3] defines behavioral intention as a measure of the strength of one's intention to perform a particular behavior.

5. Actual Use (AU)

[6] quoted from Igbaria (1994), Nelson (1996), Luthans (1995) also mentions that the individual and collective acceptance of the use can be explained from the variation usage of a system, as it is believed that the use of an ITbased system can improve the performance of individual or organizational performance. Actual use is measured in terms of the frequency of use of the system and the volume of use of the system by users.

While the influence of psychological proces CONSTRUCTS 3 Attachment (psychological attachment) is based on the concept of [4] in this study include:

1. Internalization (INT)

According to [4] in [3], the process of internalization would affect the behavior of an individual when the individual is getting/receiving influence, because the behavior is equal to its value system.

2. Identification (IDN)

[4] in [3], defined as the process of identification of the effect of psychological attachment that will affect the behavior of an individual when the individual accepts influence because he wants to achieve self-affirmation or arrange a satisfactory relationship to another person or group.

3. Compliance (COMP)

[4] in [3], compliace process (compliance) will affect the behavior of an individual when the individual is not bound to adopt the behavior because he believed in it, but his desire to get rewards or avoid punishment.

[3] who did research on " Expanded use of TAM to Explain the Effects of Psychological Attachment[3]: Basic Theory and Empirical Endorsements ". This research is to understand the role of attachment in the psychological effect of TAM under the influence of psychological attachment theory hatched Kelman on the use of MS - Exchange and Schedule + on a U.S. national health organization consisting of several hospitals located in the Midwestern city. Data were analyzed using SPSS v.19 assistance. This study proved that the influence of psychological attachment has an important role in determining the behavior of users on the use and acceptance of new information technologies. The study also proved that user perception of system usefulness (PU), perceived ease of use of the system (PEOU) and Psychological Attachment (PA) has a positive effect on user attitudes toward the use of the system (ATU) in relation to the internalization and identification. While adherence (compliance ) has a negative effect on user attitudes toward the use of the system (ATU). In addition, research has shown that user perception of system usefulness (PU) and user attitudes towards the use of the system (ATU) positive effect on behavioral intention to use the system (BI). Mean while, Psychological Attachment (PA) has no direct influence on behavioral intention to use the system (BI). However, indirectly Psychological Attachment (PA) effect on behavior intention in the use of the system (BI) via the user attitude towards the use of the system (ATU) in relation to the internalization and identification. This study also shows that the intention in the use of system behavior (BI) influence the use of the system (AU).

Based on the above description, the formulation of hypotheses to be tested are:

H1: There is a significant effect of PU, PEOU, PA to the ATU either partially or jointly.

$\mathrm{H} 2$ : There is the influence of PU, PEOU, PA, ATU to BI partially or jointly.

H3: There is the influence of PU, PEOU, PA, ATU, BI against AU either partially or jointly.

\section{RESEARCH METHODOLOGY}

Object of this study is the psychological attachment to the use of the SPSS application based on the Technology Acceptance Model. The unit is a research student of S1-psychology, while the unit of analysis is the final year of a degree candidate $\mathrm{X}$ University in Jakarta.

The independent variables consist of User Perceptions of the Usefulness apliaksi SPSS (PU), Perceptions of Ease of Use apliaksi SPSS (PEOU), Psychological Attachment (PA) which includes Internalizing (INT), Identification (IDN) and Compliance (COMP) , User Attitudes towards Using application SPSS (ATU) and Behavioral intention in application use of SPSS (BI). While the dependent variable is the use of SPSS (AU).

Survey has been done and a set of questionnaire results of the adoption of the model [3] distributed to the primary data collection instrument.

Data analysis technique that has been done is test reliability and validity, analysis of the third factor Attachment Psychological variables and path analysis.

\section{RESULTS}

A total of 120 questionnaires distributed to respondents, but only 108 questionnaires were returned and complete. 
Table 1 Results of Test Reliability and Validity

\begin{tabular}{|c|l|c|c|}
\hline \multirow{2}{*}{ No } & \multirow{2}{*}{ Reliability } & \multicolumn{2}{|c|}{ Realibility Statistic } \\
\cline { 3 - 4 } & $\begin{array}{c}\text { Cronbach's } \\
\text { Alpha }\end{array}$ & $\begin{array}{c}\text { N of } \\
\text { items }\end{array}$ \\
\hline 1 & PU & .870 & 6 \\
\hline 2 & PEOU & .770 & 6 \\
\hline 3 & ATU & .827 & 4 \\
\hline 4 & BI & .775 & 4 \\
\hline 5 & AU & .697 & 3 \\
\hline 6 & PA & .868 & 10 \\
\hline
\end{tabular}

The results of the reliability test using Cronbach Alpha, all the items are collected through research is a reliable instrument with Alpha coefficients for the instrument User Perceptions on the use of SPSS (PU) of 0.870, Perception of ease of application SPSS (PEOU) of 0.770 , User Attitudes toward the use of SPSS (ATU) of 0.827, Behavioral intention in Using SPSS aPPLICATIONS (BI) for 0.775, Using SPSS APPLICATIONS (AU) of 0.697 and Psychological Attachment (PA) of 0.868. Furthermore, after the test the validity of all items are said to be valid questions.

From the analysis of the three factors stated that Attachment Psychological variables are able to explain the most dominant variable is the variable of Psychological Attachment Identification (IDN). This is consistent with the theory that the psychological effect of attachment in the form of Identification (IDN) will increase in the level of acceptance (use) personally to the system (Kelman, HC., 1958).

Calculation shows the $\mathrm{R}$ Square or coefficient of determination equal to 0.312 , which means that $31.2 \%$ of User Attitudes towards Using SPSS APPLICATIONS (ATU) together (simultaneously) is influenced by variables PU, PEOU and PA, while the rest $(100 \%-31.2 \%=68.8 \%)$ is influenced by other variables. It found that the calculated $\mathrm{F}$ 44.710 with a significance level of 0.000 . therefore the probability is smaller than 0.05 means the regression model can be used to predict the ATU. Also note also that the regression coefficient for the variable of 0.185 PU with sig level . 0.000, therefore the probability is less than 0.05 then the hypothesis in this study for the variable PU partially accepted, which means there is significant influence between variables PU to ATU. PEOU variable regression coefficient of -0035 with the level of sig . 0.256 , therefore the probability is greater than 0.05 then the hypothesis in this study for variable PEOU partially rejected, which means there is no significant effect between the ATU PEOU variables, while the regression coefficient for the variable of 0.432 with a level PA sig . 0.000 , therefore the probability is less than 0.05 then the hypothesis in this study for the PA variables partially accepted, which means there is significant influence between variables PA to ATU.

Calculation shows the $\mathrm{R}$ Square or coefficient of determination of 0.412 , meaning that $41.2 \%$ of Behavior Intention in Using SPSS APPLICATIONS ( BI ) jointly ( simultaneously ) is influenced by variables PU, PEOU, PA and ATU, while the rest $(100 \%-31.2 \%=58.8 \%)$ is influenced by other variables. It found that the calculated $\mathrm{F}$ $51.617 \mathrm{sig}$ level .0 .000 . therefore the probability is smaller than 0.05 means the regression model can be used to predict $\mathrm{BI}$. Also note also that the regression coefficient for the variable of $0.179 \mathrm{PU}$ with sig level . 0.000 , therefore the probability is less than 0.05 then the hypothesis in this study for the variable PU partially accepted, which means there is significant influence between variables PU to BI . PEOU variable regression coefficient of 0.034 with a level of sig . 0.237 , therefore the probability is greater than 0.05 then the hypothesis in this study for variable PEOU partially rejected, which means there is no significant effect between the variables PEOU to BI . Regression coefficient for the variable of 0.266 with a level PA sig . 0.000 , therefore the probability is less than 0.05 then the hypothesis in this study for the PA variables partially accepted, which means there is significant influence between variables PA to BI. While the regression coefficient for the variable of 0.255 with a level ATU sig . 0.000 , therefore the probability is less than 0.05 then the hypothesis in this study for variable ATU partially accepted which means there is significant influence between variables ATU to BI .

Calculation shows the $\mathrm{R}$ Square or coefficient of determination of 0.138 , meaning that $13.8 \%$ of APPLICATIONS Using SPSS (AU) together (simultaneously) is influenced by variables PU, PEOU, PA, ATU and BI, while the rest $(100 \%-13.8 \%=86.2 \%)$ is influenced by other variables. It found that the calculated $\mathrm{F}$ 9.428 with the level of sig . 0.000 . therefore the probability is smaller than 0.05 means the regression model can be used to predict the AU. Also note also that the regression coefficient for the variable of -0.021 with PU sig level. 0624, therefore the probability is greater than 0.05 then the hypothesis in this study for the variable PU partially rejected, which means there is no significant effect between the variables of PU against AU. PEOU variable regression coefficient of 0.130 with a level of sig . 0000, therefore the probability is less than 0.05 then the hypothesis in this study for variable PEOU partially accepted, which means there is significant influence between variables PEOU against AU. Regression coefficient for the variable of 0.156 with a level PA sig . 0.020 , therefore the probability is less than 0.05 then the hypothesis in this study for the PA variables partially accepted, which means there is significant influence between variables PA against AU, while the regression coefficient for the variable of -0.002 with ATU sig level . 0.967, therefore the probability is greater than 0.05 then the hypothesis in this study for variable ATU partially rejected, which means there is no significant effect between the variables ATU against AU. BI regression coefficient for the variable rate of 0,048 to sig . 0.419 , therefore the probability is greater than 0.05 then the hypothesis in this study for the BI variable partially rejected, which means there is no significant effect between the variables of BI against AU.

\section{CONCLUSION AND FUTURE WORK}

Student Attitudes SPSS users are influenced by the benefits of the SPSS application Attachment and psychological influences that factor identification. Student's intention to use SPSS heavily influenced by the benefits of the application of SPSS, and a positive attitude that dominated psychological factors identified in Attachment. The use of SPSS by psychology students in this study are influenced by the ease of the application and the dominant influence of psychological factors on the identification of Attachment.

Further research carried out by loading variables individual characteristics, such as habits in the use of new information technologies, majoring in high school; SPSS applications such as training courses or workshops, and hard skills and soft skills and competencies such as GPA.

\section{REFERENCES}

[1] Davis, Fred D., Bagozzi, R. P., and Warshaw, P. R,. 1989. "User Acceptance of Computer-Technology: A Comparison of Two Theoritical Models". Management Science, 35. pp. 982-1003. 
[2] Davis, Fred D. 1989. "Percieved Usefulness, Percieved Ease of Use, and User Acceptance of Information Technology”. MIS Quartely, 13. pp. 319-340.

[3] Malhotra, Yogesh dan Dennis F. Galletta. 1999. "Extending the Technology Acceptance Model to Account for Social Influence: Theoretical Bases and Empirical Validation". Proceedings of the $32^{\text {nd }}$ Hawai International Conference on System Sciences.

[4] Kelman, H. C. 1958. "Compliance, Identification, and Internalization: Three Processes of Attitude Change?". Journal of Conflict Resolution , 2. pp. 51-60.

[5] Ernawaty, Yulia n Ediraras, Dharma T.. 2006. Analisa Penggunaan Perangkat Lunak Akuntansi dengan Pendeketan Technology Acceptance Model (TAM). Skripsi Fakultas Ekonomi Universitas Gunadarma. Jakarta.
[6] Nasution, Fahmi Natigor. 2004. "Penggunaan Teknologi Informasi Berdasarkan Aspek Perilaku (Behavioral Aspect)". (On Line) Via http://library.usu.a.id/download/fe/akuntansi_fahmi2.pdf.

[7] Hermana, Budi, Rakhma Oktavina, dan Ida Farida. 2004. "Model Adopsi Perencanaan Sumber Daya Perusahaan pada Perusahaan Manufaktur dengan Model Penerimaan Teknologi : Reliabilitas dan Validitas”. Jurnal Teknologi \& Rekayas. Vol. 9. No. 3. 157-169 Desember.

[8] Budi, Triton Prawira. 2006. SPSS 13.0 Terapan Riset Statistik Parametrik. Andi. Yogyakarta.

[9] Santoso, Singgih. 2005. Seri Solusi Bisnis Berbasis TI: Menggunakan SPSS untuk Statistik Multivariat. PT Elex Media Komputindo. Jakarta.

[10] 2006. Seri Solusi Bisnis Berbasis TI: Menggunakan SPSS dan Excel untuk Mengukur Sikap dan Kepuasan Konsumen. PT Elex Media Komputindo. Jakarta. 